\title{
DIABETES RISK FACTOR SCREENING IN ADULTS USING PERKENI QUESTIONNAIRE AND ORAL GLUCOSE TOLERANCE TEST IN SOCAH COUNTY, BANGKALAN
}

\author{
Radin H. Kamal ${ }^{1}$, Dwiki Novendrianto ${ }^{1}$, Faizah Chadijah ${ }^{1}$, Galan Budi Prasetya ${ }^{1}$, Gilang Satria Pratama ${ }^{1}$, \\ Mentari Octarina Ariadnya ${ }^{1}$, Nikita Gladys Larasati ${ }^{1}$, Nur Lia F. Darain ${ }^{1}$, Ovitrani Nanda ${ }^{1}$, Silvi Mavita ${ }^{1}$, \\ Usamah $^{1}$, Jongky Hendro Prajitno ${ }^{2}$ \\ ${ }^{1}$ Faculty of Medicine, Universitas Airlangga, Surabaya, Indonesia, ${ }^{2}$ Endocrine \& Metabolism Division, Department of \\ Internal Medicine, Faculty of Medicine \& Dr. Soetomo General Hospital, Surabaya, Indonesia
}

\begin{abstract}
ABSTRAK
Di Indonesia, terdapat 8,4 juta pasien diabetes dewasa dan sebagian besar belum terdiagnosis. Skrining untuk diabetes sangatlah penting. PERKENI merekomendasikan penggunaan kuesioner dan Tes Toleransi Glukosa Oral (TTGO) sebagai alat skrining faktor risiko. Tujuan dari penelitian ini adalah untuk mengetahui kegunaan kuesioner PERKENI dan TTGO pada orang dewasa sebagai alat uji skrining faktor risiko diabetes. Penelitian ini adalah penelitian deskriptif cross sectional yang dilakukan pada tahun 2015 di Kecamatan Socah, Bangkalan. Seluruh responden $(n=91)$ diwawancarai mengenai faktor risiko diabetes menggunakan kuesioner PERKENI, serta dilakukan pengukuran antropometri (berat badan, tinggi badan dan lingkar perut). Hasilnya dikategorikan sebagai berikut: risiko sangat rendah, risiko meningkat, risiko sedang dan risiko tinggi. Hanya peserta yang dikategorikan sebagai risiko tinggi diminta untuk melakukan TTGO. Kriteria eksklusi pada penelitian ini adalah peserta yang sebelumnya sudah didiagnosis diabetes oleh dokter dan/atau rutin meminum obat antidiabet, meminum obat-obatan dalam kurun waktu dua minggu terakhir dan tidak menyelesaikan prosedur hingga tuntas. Dari 91 peserta yang memenuhi syarat, terdapat 9 (9,89\%) peserta yang dikategorikan berisiko tinggi. Hasil TTGO dari peserta tersebut adalah: 4 dalam batas normal, 1 menderita Toleransi Glukosa Terganggu (TGT), dan 4 baru terdiagnosis diabetes. Sebagai simpulan, penggunaan kuesioner PERKENI dan TTGO pada populasi dewasa berisiko tinggi sebagai alat skrining faktor risiko diabetes meningkatkan penemuan kasus diabetes baru. Hasil analisis kami dapat mendukung penggunaan kuesioner dan TTGO sebagai metode skrining faktor risiko pada populasi dewasa berisiko tinggi, terutama pada sumber daya yang minim. (FMI 2017;53:199-203)
\end{abstract}

Kata kunci: Diabetes; dewasa; skrining faktor risiko; kuesioner PERKENI; Tes Toleransi Glukosa Oral

\begin{abstract}
There are 8.4 million diabetes adult patients in Indonesia and most remained undiagnosed. Screening process for diabetes is very important. PERKENI has recommended the use of questionnaire and Oral Glucose Tolerance Test (OGTT) as risk factor screening tools. This study aimed to find out the use of PERKENI questionnaire and OGTT in adults as diabetes risk factor screening tools. This was a descriptive cross sectional study conducted in 2015 in Socah County Bangkalan. Participants $(n=91)$ were interviewed regarding diabetes risk factor using PERKENI questionnaire. Anthropometric (height, weight, and abdominal circumference) measurements were also taken. The results were categorized into: very low risk, increased risk, moderate risk and high risk. Only those categorized as high risk were asked to take OGTT. Exclusion criteria were participants who had been diagnosed with diabetes by a physician and/or routinely taking anti diabetic medication, consumed drugs during the previous two weeks and does not finish the required procedures. From 91 eligible participants, only 9 (9.89\%) were categorized as high risk. The result of OGTT were: 4 were within normal limit, 1 had impaired glucose tolerance (IGT) and 4 were newly diagnosed with diabetes. The use of PERKENI questionnaire and OGTT in high risk adult population as a diabetes risk factor screening tool increased new findings of diabetes cases. Our analysis may support the adoption of diabetes risk factor screening methods through questionnaires and OGTT in high risk adult population, especially in low resource setting. (FMI 2017;53:199-203)
\end{abstract}

Keywords: Diabetes; adults; risk factor screening; PERKENI questionnaire; Oral Glucose Tolerance Test

Correspondence: Radin H Kamal, Faculty of Medicine, Universitas Airlangga. Jl. Mayjen. Prof. Dr. Moestopo No. 47 Surabaya, East Java, Indonesia. Email: rdn_kml@ hotmail.com

\section{INTRODUCTION}

Diabetes is a major health problem in Indonesia and still on a steady increase from year to year (WHO 2015, IDF 2015). This increase may be seen from the prevalence of $2.3 \%$ to $5.7 \%$ in 2013 (BPPK 2013). The prevalence of diabetes in adults from 2000 will be doubled by 2030 (Wild et al 2004). In Indonesia, there are 8.4 million adult diabetic patients (PERKENI 2011). Only 30.4\% of those patients had been diagnosed and $69.6 \%$ remained undiagnosed (BPPK 2013). However, various risk factors for diabetes continue to rise each year. Early 
clinical diagnosis in diabetes is difficult to do because the signs and symptoms that occur early in the natural history of the disease are frequently hard to recognized (Valliyot et al 2013, Ndraha 2014).

Early screening and recognition is important (Ndraha 2014, InfoDATIN 2014). Screening is fairly important for the detection of disease in asymptomatic patients, apparently healthy individuals if the burden of the disease is large, the natural history of the disease process is understood, effective treatment exists, early treatment is more effective than later treatment and the screening procedure is good (Herman et al 1995, Engelgau et al 2000). Diabetes and its complications will have a direct impact on human resources and greatly increases medical costs. Education, prevention and early recognition should also be top priority in its management (PERKENI 2011). Screening test may be used to screen and hopefully detect the disease early on. Professional diabetes associations around the world have recommended the adoption of risk factor screening tests at risk population. PERKENI has also recommended screening test use and also published its own questionnaire and OGTT as screening tools for the general population, especially in high risk adult population. The aim of this study was to find out the use of PERKENI questionnaire and OGTT in adults as diabetes risk factor screening tools.

\section{MATERIALS AND METHODS}

This study was conducted in Socah County, Bangkalan. Data were collected from November 13th-15th 2015. The study type was observational with descriptive cross sectional study design. The study population was all adults in Socah County, Bangkalan. Total sample of 108 participants was selected using accidental sampling method.

The inclusion criterion in this study was adults in Socah County, Bangkalan who consented to participate in the study. The procedures were: after obtaning informed consent, the participant's data on the PERKENI questionnaire was collected through an interview preceded by anthropometric (height, weight, and abdominal circumference) measurements by researchers. The results were categorized into: very low risk, increased risk, moderate risk and high risk. Only those who were categorized as high risk were asked to take OGTT according to the standard operational procedures (PERKENI 2011) with capilary blood glucose monitor (Accu-Chek® Active Blood Glucose Meter; Roche Diagnostics). All participants received information and education about diabetes accordingly. The exclusion criteria were: 1) participant who had been diagnosed with diabetes by a physician and/or taking anti-diabetic medication, 2) consumed drugs during the previous two weeks, 3) participant who does not finish the questionnaire and OGTT. Participants data were presented descriptively. Univariate data analysis was used for statistical analysis. The Airlangga School of Medicine Community Medicine Coordination Bureau approved the study protocol, consent process, and all study related procedures.

\section{RESULTS}

Out of 108 participants, 17 were all already diagnosed with diabetes by a physician and met the exclusion criteria. Total data included in the study were 91 eligible participants. Eighty-six $(94.51 \%)$ participants were female with median age of 42 (range 24-70) years old.

Table 1. Participants' characteristics

\begin{tabular}{|c|c|c|}
\hline Risk factor & $\begin{array}{c}\text { Frequency } \\
\text { (Participant) }\end{array}$ & $\begin{array}{c}\text { Percentage } \\
(\%)\end{array}$ \\
\hline \multicolumn{3}{|l|}{ Age (year old) } \\
\hline$<45$ & 44 & 48.3 \\
\hline $45-55$ & 20 & 21.98 \\
\hline $55-65$ & 16 & 17.58 \\
\hline$>65$ & 11 & 12.09 \\
\hline \multicolumn{3}{|l|}{ Sex } \\
\hline Male & 5 & 5.49 \\
\hline Female & 86 & 94.51 \\
\hline \multicolumn{3}{|c|}{ Abdominal Circumference $(\mathrm{cm})$} \\
\hline$<80$ & 23 & 25.27 \\
\hline $80-90$ & 43 & 47.25 \\
\hline$>90$ & 25 & 27.4 \\
\hline \multicolumn{3}{|l|}{ Body Mass Index } \\
\hline$<23$ & 39 & 42.86 \\
\hline $23-25$ & 30 & 32.97 \\
\hline$>25$ & 22 & 24.18 \\
\hline
\end{tabular}

Table 2. PERKENI questionnaire results

\begin{tabular}{lcc}
\hline Risk factor category & $\begin{array}{c}\text { Frequency } \\
\text { (Participant) }\end{array}$ & $\begin{array}{c}\text { Percentage } \\
(\%)\end{array}$ \\
\hline Very Low Risk & 36 & 39.56 \\
Increased Risk & 43 & 47.25 \\
Moderate Risk & 3 & 3.30 \\
High Risk & 9 & 9.89 \\
\hline Total $(\mathrm{n})$ & 91 & 100.0 \\
\hline
\end{tabular}

Table 3. OGTT results

\begin{tabular}{lcc}
\hline \multicolumn{1}{c}{ Result } & $\begin{array}{c}\text { Frequency } \\
\text { (Participant) }\end{array}$ & $\begin{array}{c}\text { Percentage } \\
(\%)\end{array}$ \\
\hline Normal & 4 & 44.44 \\
Impaired Glucose Tolerance & 1 & 11.11 \\
Diabetes & 4 & 44.44 \\
\hline Total $(\mathrm{n})$ & 9 & 100.0 \\
\hline
\end{tabular}


Only $9(9.89 \%)$ out of 91 participants were categorized as high risk. The results of OGTT showed that 4 participants had normal limit, 1 participant had IGT and 4 participants were newly diagnosed with diabetes.

\section{DISCUSSION}

Based on the results, 91 participants met the inclusion criteria. About $48.35 \%$ participants were $<45$ years old, $21.98 \%$ participants were $45-55$ years old, $17.58 \%$ participants were 55-65 years old and the remaining of $12.09 \%$ were $>65$ years old in descending order. The prevalence of diabetes mellitus proportion increases with age (BPPK 2013), however, it is not shown in our study. The most participants were <45-year-olds because they showed up to participate in the study more than any age group. Thus, the number might not reflect the actual age statistics of Socah County. Risk factor screening becomes more important year by year, as older age comes with higher risks (Wild et al 2004, PERKENI 2011). Risk factor screening test needs to be done as early as possible.

Almost all participants were female. According to sex, the proportion of patients with diabetes and IGT are higher among females. This difference was found not only on an epidemiological point of view, but also on the outcome of treatment regiments (Perreault et al 2008). However, the sex proportion in current study might not represent the actual statistics in the area. The domination of female participants was due to the limitation of sampling method. In Socah County, most of men were sailors and most of women were housewives, thus adult female became the participants with the most number. Future studies need to have equal portions of both sexes.

This study showed that $27.47 \%$ of participants had abdominal circumference $>90 \mathrm{~cm}$ and $24.18 \%$ had BMI $>25$. Higher abdominal circumference and BMI increases the risk of diabetes. Fat cells that undergo hypertrophy decrease the number of insulin receptors. Higher fatty acids content in the body increases Resistin and Adiponectin, which in turn decreases the sensitivity of insulin receptors. Hence, they increase insulin resistance (Fujimoto et al 2007). Reduced abdominal circumference and BMI correlates with lower risk and occurrences of diabetes (Fujimoto et al 2007, Ndraha 2014). Out of 91 participants, more than $50 \%$ had increased risks for diabetes. The risk factor screening test was used as a method of early recognition of increased risks and hopefully as a prevention method of diabetes (Fujimoto et al 2007, Hoerger et al 2007).
OOGT results on 9 participants who were categorized as high risk showed that 4 participants had normal limit, 1 $(11.11 \%)$ had IGT and $4(44.44 \%)$ were newly diagnosed with diabetes. There were $9.89 \%$ of all eligible participants who were at high risk, and $4.3 \%$ suffered diabetes. IGT is a transitional state between normal function and diabetes. People with IGT had increased risk of developing diabetes (Fujimoto et al 2007, PERKENI 2011). Risk factor screening and OGTT should be done as an early detection on high risk population to have early interventions such as lifestyle changes and pharmacological intervention (The Diabetes Prevention Program Research Group 2012). On their study, Christophi et al (2013) showed that the use of OGTT in high risk adult population as a screening tool is more sensitive compared to fasting plasma glucose to confirm the occurrence and diagnosis of diabetes.

In recent years, the International Expert Committee and The American Diabetes Association have also recommended the use of HbA1c as a tool to monitor blood glucose control and for diagnosing diabetes. However, Christophi et al (2013) argued that OGTT would likely to remain a common screening approach in making the diagnosis, especially in countries where HbAlc is not readily available. We also demonstrated the use of our screening test as a platform for information, education and to increase awareness regarding the prevention of diabetes. We believe this benefit could also be found in similar tests on similar diseases, either in office-based settings or targeted community-based settings (Engelgau et al 2000).

The prevention of diabetes and earlier treatments are effective to reduce the costs, and the prospect of lower diabetes occurrences will in turn lower the possible burden of diabetes complications on quality of life, work productivity and medical costs (Wild et al 2004, Alberti et al 2007, The Diabetes Prevention Program Research Group 2012, Herman et al 2013). The combination of questionnaire and OGTT in high risk population is relatively cheaper when compared with other methods (Hoerger 2007, Herman 2013). Screening test may increase early identification and treatment in increased to high risk adult population. The cost of diabetes with complications can rise up to $250 \%$ compared to diabetes without complication (Waugh et al 2007). Hence, earlier identification and treatment may substantially decrease the possible burden of diabetes on the long run.

The IDF has also recommend the use of opportunistic screening test by health-care professionals to identify diabetes patients at risk (Alberti et al 2007). In Hoerger et al's (2007) study, using screening method of office interviews and random capillary blood glucose can 
triple the number of patients receiving medical instructions and treatment regimens. However, using questionnaire alone as a screening tool generally results in poor performance. It is also summarized that the sensitivity of diabetes risk factor questionnaire was around $56 \%$ and its specificity was $72 \%$ (Engelgau et al. 2000), even though mass-screening method using blood glucose test is not recommended since it is not cost-effective at all (PERKENI 2011).

Engelgau et al (2000) stated in their report that population-based and selective community screenings consumed considerable costs and might not have positive long-term impact on health. However, they argued that opportunistic screening in high risk adult population consumed fewer resources and might provide better follow-up. The effectiveness of different strategies for diabetes screening highly depended on the population that was evaluated. A two-stage screening test, such in this study, may provide a more efficient use of resources (Engelgau et al 2000, Waugh et al 2007). Furthermore, diabetes screening may also be combined with other efforts to detect other medical conditions, such as hypertension and dyslipidemia (Engelgau et al 2000). Thus, it is possible that using simple questionnaire and OGTT can be done in a cost-effective way to targeted high risk adult population, especially in low resource settings.

Diabetes risk factor screening using questionnaire and OGTT in high risk adult population may provide a costbenefit effect to patients and medical providers (insurance companies, national programs, governments, etc.) in the long run. All stakeholders should coordinate, advocate and legislate the regulatory measures to address diabetes as an illness (Engelgau et al 2000, Alberti et al 2007). Indonesia already has Posbindu PTM national program (Pos Pembinaan Terpadu Penyakit Tidak Menular/Integrated Non-Communicable Diseases Post) (InfoDATIN 2015) and should be used as a platform for screening. However, the use of screening tests alone will not be enough since multidisciplinary approach of a coordinated health, finance and education sector is needed to stop and reverse the rise of diabetes.

Out of 108 participants who had consented to participate in this study, $21(19.4 \%)$ were found to be diabetics. Socah County had more diabetes occurrences (twice higher) than the estimated global prevalence by 2030 of $7.2 \%$ (Wild et al 2004). This number may not reflect the real prevalence of diabetes, as one study revealed that the prevalence of diabetes in Bangkalan was $3.848 \%$ in 2012 (Wulandari \& Isfandiari 2013). However, it is interesting since the high occurrence of diabetes was found in Socah County.
A limitation in our study was that our study took only a short period of time. The sampling method we chose were more practical to be applied in Socah County. Future studies should have larger and more heterogeneous samples. Another limitation in our study was almost all of our participants were female. Therefore, our results may not be applicable outside the population of the current study. Further study should be conducted to investigate the closest prevalence of diabetes in Socah County, Bangkalan.

\section{CONCLUSION}

The use of PERKENI questionnaire and Oral Glucose Tolerance Test in high risk adult population as a diabetes risk factor screening tool increased new findings of diabetes cases. Diabetes risk factor screening may have benefits when it used in targeted high risk population since it increases awareness, early recognition, preventive measures, early treatment regiments and other medical conditions, especially in low resource setting. Our analysis may support the adoption of diabetes risk factor screening methods through questionnaire and OGTT in high risk adult population, especially in low resource setting.

\section{REFERENCES}

Alberti KGMM, Zimmet P, Shaw J (2007). International diabetes federation: a consensus on type 2 diabetes prevention. Diabetic Medicine 24, 451-463

Badan Penelitian dan Pengembangan Kesehatan (2013). Riset Kesehatan Dasar (RISKESDAS), Kementerian Kesehatan RI, Jakarta

Christophi CA, Resnick HE, Ratner RE, et al (2013), confirming glycemic status in the diabetes prevention program: implication for diagnosing diabetes in high risk adults. J Diabetes Complications 27, 150-7

Engelgau MM, Narayan KMV, Herman W (2000). Screening for type 2 diabetes. Diabetes Care 21, 15631580

Fujimoto WY, Jablonski KA, Bray GA, et al (2007). Body size and shape changes and the risk of diabetes in the diabetes prevention program. Diabetes 56, 1680-5

Herman WH, Edelstein SL, Ratner RE, et al (2013). Effectiveness and cost-effectiveness of diabetes prevention among adherent participants. Am J Manag Care 19, 194-202

Herman WH, Smith PJ, Thompson TJ, Engelgau MM, Aubert RE (1995). A new and simple questionnaire to identify people at increased risk for undiagnosed diabetes. Diabetes Care 18, 382-7 
Hoerger TJ, Hicks KA, Sorensen SW, et al (2007), Cost-effectiveness of screening for pre-diabetes among overweight and obese U.S. adults. Diabetes Care 30, 2874-9

InfoDATIN (2014), Situasi dan analisis diabetes. Kementerian Kesehatan RI, Jakarta Selatan

International Diabetes Federation (2015). Diabetes Facts and Figures. Available from http://www. idf.org/ WDD15-guide/facts-and-figures.html. Accessed November 19,2015

Ndraha S (2014). Diabetes mellitus tipe 2 dan tatalaksana terkini. Departemen Penyakit Dalam Fakultas Kedokteran Universitas Krida Wacana, Jakarta

PERKENI (2011). Konsensus pengelolan dan pencegahan diabetes melitus tipe 2 di Indonesia, PB PERKENI, Jakarta

Perreault L, Ma Y, Dagogo-Jack S, et al (2008). Sex differences in diabetes risk and the effect of intensive lifestyle modification in the diabetes prevention program. Diabetes Care 31, 1416-21

The Diabetes Prevention Program Research Group (2012). The 10-year cost-effectiveness of lifestyle intervention or metformin for diabetes prevention. Diabetes Care 35, 723-30

Valliyot B, Jayadevan S, Jayakumary M, Sudha BV (2013). Risk factors of type 2 diabetes mellitus in the rural population of North Kerala, India: a case control study. Diabetologia Croatia 42, 33-40

Waugh N, Scotland G, McNamee P, et al (2007). Screening for type 2 diabetes: literature review and economic modelling. Health Technology Assessment 11

Wild S, Gojka R, Anders G, Richard S, Hilary K (2004). Global prevalence of diabetes: estimates for the year 2000 and projections for 2030', Diabetes Care 27, 1047-53

World Health Organization (2015). Diabetes mellitus fact sheet. Available from www.who.int/mediacentre/factsheets/fs138/en. Accessed November 23, 2015

Wulandari MY, Isfandiari MA (2013). Kaitan sindroma metabolik dan gaya hidup dengan gejala komplikasi mikrovaskuler. Jurnal Berkala Epidemiologi 1, 22423. 